\title{
Ochrona klimatu jako obowiązek etyczny. Kwestia klimatyczna w encyklice Laudato si'
}

\author{
Zbigniew M. Karaczun \\ Wydział Ogrodnictwa, Biotechnologii i Architektury Krajobrazu \\ Szkoły Głównej Gospodarstwa Wiejskiego w Warszawie, \\ Katedra Ochrony Środowiska, Nowoursynowska 166, 02-767 Warszawa, zbigniew_karaczun@sggw.pl
}

\section{Streszczenie}

Powstrzymanie antropogennej zmiany klimatu należy do najważniejszych wyzwań, przed jakimi stoi współczesne pokolenie. Zagadnienie to jest jednym z tematów poruszonych w encyklice papieża Franciszka Laudato si'. Przyjmując za wiarygodne wyniki badań naukowych, wskazujących, że to człowiek odpowiada za obserwowane zmiany, papież wskazuje na przyczyny niszczenia przez człowieka klimatu, omawia, jak niebezpieczne mogą być ich skutki i wzywa do większej aktywności w ochronie klimatu. Analizowany dokument nie przedstawia jednak rozwiązań technicznych. Tym, co odróżnia encyklikę Laudato si' od innych dokumentów dotyczących ochrony środowiska, jest nacisk, jaki papież kładzie na kwestie etyczne i moralne. Jednoznacznie wskazuje, że główną przyczyną obecnego kryzysu klimatycznego jest chciwość i egoizm. Dlatego w ocenie Autora niezbędne są przede wszystkim zmiany postaw ludzkich, solidarność ze słabszymi i wzrost odpowiedzialności za los przyszłych pokoleń. Celem artykułu jest analiza podejścia papieża do potrzeby ochrony klimatu oraz omówienie trzech głównych wyzwań, jakie papież wskazuje w tym zakresie: potrzeby zaufania nauce, wezwania do solidarności i apelu o aktywniejsze działania - 0 odwagę i większą odpowiedzialność w procesie podejmowania decyzji.

\section{Słowa kluczowe}

encyklika Laudato si', zmiany klimatu, ochrona klimatu, etyka

\section{Wprowadzenie}

Początek współczesnego myślenia o ochronie środowiska można wiązać z opublikowaną w 1962 roku książką Silent Spring (Cicha wiosna) amerykańskiej biolog $\mathrm{Ra}$ chel Carson (Carson 1962), w której autorka przedstawiała negatywne konsekwencje zanieczyszczenia środowiska pozostałościami pestycydów, przede wszystkim DDT. Informacje zawarte w tej publikacji wywołały bardzo szeroki odzew w całych Stanach
Zjednoczonych, przyczyniając się m.in. do utworzenia amerykańskiej, federalnej służby ochrony środowiska US EPA i powstania pierwszych ruchów ekologicznych.

W kolejnych latach pojawiły się jeszcze kilka opracowań, które miały podobną siłę oddziaływania. W sierpniu 1969 roku w trakcie XXIII Sesji Zgromadzenia Ogólnego ONZ wystąpił Sekretarz Generalny tej organizacji Sithu U'Thant. Przedstawił on wówczas wnioski ze swoich analiz, 
dokument, nazwany później Raportem U'Thanta (U'Thant 1969), prezentujący dane o postępującej degradacji środowiska przyrodniczego. Wskazywał on na nasilającą się presję rozwoju gospodarczego i cywilizacyjnego na środowisko i związane z tym negatywne zjawiska, takie jak: degradacja gleb uprawnych, zanieczyszczenie i zmniejszanie dostępnych zasobów wód, niekontrolowany rozrost miast i postępująca utrata wielu gatunków zwierząt i roślin. Podstawową myślą raportu była teza, że niszczenie środowiska ma charakter globalny, a proces staje się tak niebezpieczny, że może zagrozić rozwojowi cywilizacyjnemu. Kilka lat później wnioski przedstawione przez U'Thanta znalazły potwierdzenie w publikacji Klubu Rzymskiego Granice wzrostu (Meadows i in. 1973). Jego autorzy ostrzegali, że „Jeśli obecne trendy wzrostowe zanieczyszczenia i zużycia zasobów [...] zostaną utrzymane, to w ciągu najbliższych stu lat osiągnięte zostaną granice wzrostu tej planety [...], skutkiem czego będzie raczej gwałtowny i niekontrolowany spadek zarówno liczebności populacji, jak i produkcji przemysłowej". Najważniejsze przesłanie raportu pozostało aktualne do dziś: ze względu na ograniczoną pojemność kuli ziemskiej, przestrzeń ekologiczna, którą dysponujemy, jest ograniczona. Tę ograniczoność powinniśmy rozumieć szeroko: jako skończoną ilość zasobów nieodnawialnych, ale także jako ograniczoną zdolność środowiska do odtwarzania zasobów odnawialnych i przyjmowania odpadów z procesów rozwojowych człowieka. Obie te publikacje przyczyniły się do ugruntowania przekonania, że tworzenie i wdrażanie celów polityki ekologicznej jest zadaniem władzy publicznej oraz do rozpoczęcia wysiłków na rzecz koordynacji tej polityki na poziomie międzynarodowym.

Najważniejszym i najbardziej znanym dokumentem z tego nurtu jest opublikowany w 1987 roku raport Our common future (Nasza wspólna przyszłość), opracowany przez zespół specjalistów i ekspertów pod kierunkiem byłej premier Norwegii Gro Harlem Brundtland (Brundtland i in. 1987).
Opracowanie to wprowadziło do politycznej i publicznej debaty pojęcie zrównoważonego rozwoju, rozumianego jako taki sposób zaspokajania potrzeb bieżącego pokolenia, który nie ogranicza możliwości rozwojowych i realizacji aspiracji przez przyszłe generacje. Z tego też względu „zrównoważony rozwój” traktować należy nie tyle jako równoważenie trzech podstawowych obszarów - środowiska społecznego, środowiska gospodarczego i środowiska przyrodniczego - ile jako taki sposób rozwoju społeczno-gospodarczego, który nie narusza podstawowych barier środowiskowych. Bariery te wyznacza możliwość odnawiania się zasobów naturalnych oraz utrzymanie podstawowych procesów ekologicznych i systemów podtrzymujących życie na Ziemi. Idea zrównoważonego rozwoju, zawarta w dokumencie Nasza wspólna przyszłość, została wykorzystana do opracowania głównych dokumentów przyjętych w 1992 roku w trakcie Szczytu Ziemi w Rio de Janeiro m.in.: Agendy 21 (Web-o1) oraz Ramowej konwencji Narodów Zjednoczonych w sprawie zmian klimatu (B).

Zaprezentowane w Raporcie Brundtland podejście do rozwoju i ochrony środowiska znalazło swoje odbicie w opublikowanej w czerwcu 2015 roku encyklice Laudato si' (Franciszek 2015). To dokument o wielkim potencjale i nowatorskim podejściu. Jeśli encyklika zostanie odpowiednio nagłośniona, może stać się kolejnym opracowaniem, które zmieni sposób, w jaki ochrona środowiska uwzględniana jest w decyzjach dotyczących kierunków rozwoju. Chociaż encyklika nie wskazuje konkretnych rozwiązań problemów występujących w tym obszarze, to omawia ich główne przyczyny: brak szacunku do innych ludzi i otaczającego nas bogactwa natury, brak pokory i solidarności z innymi, nieopanowana chciwość, brak moralności współczesnego świata polityki i korporacji. Jej punktem wyjścia jest wezwanie do większej solidarności, zarówno z najuboższymi, jak i z przyszłymi pokoleniami. Wskazuje także na potrzebę refleksji i zrozumienia odpowiedzialności, jaką każdy z nas ponosi za stan środowiska przyrodniczego. 
Encyklika Laudato si' dotyka wszystkich, najważniejszych współcześnie problemów ekologicznych. W sposób szczególny odnosi się jednak do naszej odpowiedzialności za klimat, „dobro wspólne”, które musimy ochronić, żeby nie doprowadzić do zagłady przyszłych pokoleń.

Celem niniejszego artykułu jest omówienie, w jaki sposób encyklika podchodzi do potrzeby ochrony klimatu, oraz analiza trzech głównych wyzwań, jakie papież wskazuje w tym zakresie: potrzeby zaufania nauce, wezwania do solidarności i apelu o aktywniejsze działania - o odwagę i większą odpowiedzialność w procesie podejmowania decyzji.

\section{Szeroki kontekst encykliki Laudato si'}

Laudato si' stanowi podsumowanie rozważań o kryzysie ekologicznym, jakie w katolickiej nauce społecznej prowadzone są od kilkudziesięciu lat. Encyklika ta, analizowana z szerszej perspektywy aktywności na rzecz ochrony klimatu zarówno Ojca św. Franciszka, jak i jego poprzedników, jest dowodem na rzeczywiste i głębokie zaangażowanie obecnego papieża oraz całego Kościoła katolickiego w działania na tym polu.

Korzenie podejścia do kwestii ekologicznych w nauczaniu Kościoła katolickiego sięgają prac Jana XXIII. Twierdził on, że przyczyn katastrofy ekologicznej (ale przede wszystkim społecznej) należy szukać w upadku duchowym współczesnego człowieka i zaniku wartości etycznych, wyznaczających kierunek jego postępowania. Zachęcał do traktowania przyrody jako własności wspólnej, którą należy się dzielić. Aby jednak można się było nią dzielić, należy o nią dbać i się o nią troszczyć. Myśli poprzednika rozwijał Paweł VI, który postulował m.in. potrzebę uporządkowania i rozwinięcia prawa ochrony środowiska, traktując to jako sposób ograniczania niepohamowanej konsumpcji, której efektem jest degradacja zasobów przyrodniczych (Web-02).

Kwestie ekologiczne i dotyczące ochrony klimatu stanowiły istotną część nauczania
Jana Pawła II. Już w swojej pierwszej encyklice Redemptor hominis zwrócił on uwagę na zagrożenie, jakie stwarza dla człowieka skażenie środowiska przyrodniczego: „[...] ów stan zagrożenia człowieka ze strony wytworów samego człowieka ma różne kierunki i różne stopnie nasilenia. Zdaje się, że jesteśmy coraz bardziej świadomi, iż eksploatacja Ziemi, planety, na której żyjemy, domaga się jakiegoś racjonalnego i uczciwego planowania" (Jan Paweł II 1979: 15).

Znacznie bardziej bezpośrednio o potrzebie ochrony środowiska mówił Jan Paweł II w trakcie swojej pielgrzymki do Polski w 1991 roku: „Zwracam się do wszystkich ludzi w całej Ojczyźnie, gdyż degradacja środowiska naturalnego jest coraz większa, a zagrożenie to w Polsce zdaje się być szczególnie alarmujące. Przyroda cierpi z powodu człowieka. Dar panowania nad przyrodą winniśmy wykorzystywać w poczuciu odpowiedzialności, świadomości, że jest to wspólne dobro ludzkości. Tu także chodzi o siódme przykazanie: «Nie kradnij!». Woda, powietrze, ziemia, las, zwierzęta, rośliny zostały stworzone przez Boga i zasługują na szacunek ze strony człowieka" (Web-o8).

Rok wcześniej, w Orędziu na XXIII Światowy Dzień Pokoju. Pokój z Bogiem Stwórcą, pokój z całym stworzeniem Święty Jan $\mathrm{Pa}$ weł II jednoznacznie wypowiedział się o potrzebie działań w celu ochrony klimatu: „Stopniowe niszczenie warstwy ozonowej i postępujący w ślad za nim «efekt cieplarniany» osiągnęły krytyczne rozmiary na skutek ciągłego rozwoju przemysłu, wielkich aglomeracji miejskich i zwiększonego zużycia energii. [...] gazy produkowane przy spalaniu kopalin, niekontrolowane wycinane lasów, stosowanie pewnych herbicydów, substancji chłodzących i aerozoli wszystko to, jak wiadomo, ma szkodliwy wpływ na atmosferę i na całe środowisko naturalne. Obserwuje się liczne zmiany klimatyczne i atmosferyczne, które niosą z sobą wielorakie konsekwencje, począwszy od szkodliwego działania na zdrowie ludzkie, a skończywszy na niebezpieczeństwie zatopienia przybrzeżnych obszarów lądu. 
Niektóre szkody są nieodwracalne, ale wiele procesów można jeszcze opanować. Dlatego cała ludzka wspólnota - jednostki, państwa i organizacje międzynarodowe - ma obowiązek wykazania się na tym polu należną odpowiedzialnością" (Web-o3).

Kwestie klimatyczne były istotne także dla następcy Jana Pawła II. W trakcie zorganizowanej w 2009 roku konferencji w Castel Gandolfo Benedykt XVI wezwał polityków do zawarcia porozumienia w trakcie szczytu klimatycznego w Kopenhadze (Grochowska 2010). Podjął on także decyzję o zamontowaniu na dachu Auli Pawła VI 2400 ogniw fotowoltaicznych generujących prąd niezbędny do ogrzania, chłodzenia i oświetlenia budynków. Dzięki temu Watykan, jako pierwsze państwo na świecie, ograniczył ilość emitowanego dwutlenku węgla do zera (Ferrisi 2012).

Nauczanie obecnego papieża w zakresie ochrony środowiska stanowi więc kontynuację, ale także rozwinięcie dorobku poprzedników. Laudato si' odnosi się do wszystkich najbardziej istotnych współczesnych problemów ochrony środowiska: oprócz zmian klimatu także do utraty różnorodności biologicznej, zanieczyszczenia wód i utrudnienia dostępu do wody pitnej odpowiedniej jakości oraz degradacji gleby.

Ochronie klimatu papież Franciszek poświęca jeden z podrozdziałów encykliki. Punkt wyjścia stanowi przekonanie, że klimat jest dobrem wspólnym, jest „wszystkich i dla wszystkich" (Franciszek 2015: 19). Dlatego wymaga ochrony i troski ze strony wszystkich ludzi, a działania powinny być prowadzone przez wszystkie państwa świata. Jak się wydaje, poprawne jest analizowanie treści encykliki nawiązującej do ochrony klimatu z szerszej perspektywy aktywności Franciszka w 2015 roku w tym obszarze. Chodzi nie tylko o wsparcie, jakie udzielił papież utworzonemu w styczniu tego roku katolickiemu ruchowi na rzecz ochrony klimatu (Global Catholic Climate Movement) (Web-o4), ale też o inicjatywy polityczne podjęte przez dyplomację watykańską i samego papieża. Również o spotkania z wieloma przywódcami państw, w trakcie których Franciszek mówił o konieczności podejmowania działań na rzecz ochrony klimatu i zawarcia międzynarodowego porozumienia w tej sprawie. Jednym z rozmówców Ojca Świętego był Barack Obama, któremu papież dziękował za inicjatywy ochrony klimatu i apelował o jeszcze aktywniejsze działania (Web-o6). We wrześniu 2015 roku na forum ONZ papież wygłosił mowę, której istotną częścią było wskazanie na potrzebę ściślejszej niż wcześniej międzynarodowej współpracy i solidarności w zapobieganiu zmianom klimatu (Web-05). Papież włączył się także w proces tworzenia europejskiej polityki klimatycznej. Na kilka dni przed spotkaniem Rady Środowiskowej UE, podczas którego miało zostać określone stanowisko Unii na 21. sesję Konferencji Stron ramowej konwencji klimatycznej, papież zaprosił ministrów środowiska państw UE do Watykanu i namawiał ich do podjęcia odważnych decyzji1.

Choć trudno jest ocenić, na ile do sukcesu konferencji paryskiej przyczyniły się wysiłki papieża, z pewnością bez jego aktywności (ale także działań przywódców innych religii światowych - m.in. Dalajlamy, biskupów i kongregacji kościołów ewangelickich i in. oraz naukowców i działaczy społecznych) osiągnięcie porozumienia byłoby trudniejsze.

\section{Kwestie klimatyczne w encyklice Laudato si'}

\subsection{Naukowe podstawy działania}

Przez wiele lat przeciwnicy działań na rzecz ochrony klimatu swój sprzeciw uzasadniali brakiem pewności naukowej, że zmiany takie rzeczywiście zachodzą, a jeśli tak, że za ich powstanie odpowiedzialny jest człowiek. Twierdzili, że wielkość emisji antropogennej jest minimalna w porównaniu z emisją

1 21. sesja Konferencji Stron ramowej konwencji Narodów Zjednoczonych w sprawie zmian klimatu odbyła się w Paryżu w grudniu 2015 roku i przyniosła podpisanie tzw. porozumienia paryskiego wyznaczającego kierunki działań społeczności międzynarodowej w tym zakresie do 2030 roku. 
ze źródeł naturalnych, więc nie może ona doprowadzić do zmiany w składzie atmosfery. Starali się udowodnić, że obserwowane zmiany spowodowane są zwiększoną aktywnością Słońca lub prowadzeniem obserwacji temperatury atmosfery w miejscach narażonych na oddziaływanie miejskich wysp ciepła (Wang i Oppenheimer 2005). Choć większość tych opinii nie miała podstaw naukowych i była skutecznie obalana przez naukowców zajmujących się badaniem klimatu, sceptyków to nie przekonywało i nadal nie przekonuje (Costella 2010).

Tymczasem wiedza na temat przyczyn zmian klimatu, ich przebiegu i prognozowanych skutków w ostatnich latach bardzo się pogłębiła. O ile bowiem na początku lat dziewięćdziesiątych pewne było jedynie to, że antropogenna emisja $\mathrm{CO}_{2}, \mathrm{NH}_{4}$ i $\mathrm{CH}_{4}$ może przyczyniać się do zwiększenia ich koncentracji w atmosferze (IPCC 1990), o tyle już na początku XXI wieku uzyskano dowody wskazujące, że od połowy XX wieku to człowiek wywierał największy wpływ na klimat (IPCC 2001). W 2013 roku opublikowany został V raport Międzyrządowego Zespołu ds. badań Zmian Klimatu, w którym stwierdzono jednoznacznie, że to działalność człowieka odpowiada za obserwowane obecnie skutki zmian klimatu, a pewność co do antropogennego wpływu na klimat wynosi ponad 95\%: „[...] wpływ człowieka na klimat jest oczywisty. Świadczą o tym rosnące koncentracje gazów cieplarnianych $\mathrm{w}$ atmosferze, dodatnie wymuszanie radiacyjne, obserwowane ocieplenie i zrozumienie systemu klimatycznego" (Web-o7).

Franciszek jednoznacznie opowiada się po stronie nauki. Pisze on m.in.: „[...] istnieje bardzo solidny konsensus naukowy wskazujący, że mamy do czynienia z niepokojącym ociepleniem systemu klimatycznego [....] .To prawda, że istnieją inne czynniki (na przykład wulkanizm, zmiany orbity i osi Ziemi, cykl słoneczny), ale liczne badania naukowe wskazują, że większość globalnego ocieplenia ostatnich kilkudziesięciu lat zawdzięczamy wysokiemu stężeniu gazów cieplarnianych (dwutlenek węgla, metan, tlenki azotu i innych), emitowanych głównie z powodu działalności człowieka" (Franciszek 2015: 23). Papież wskazuje także przyczyny obserwowanych zmian klimatu. W jego przekonaniu to przede wszystkim wzorzec rozwoju oparty na intensywnym wykorzystaniu paliw kopalnych oraz zmiany w sposobie użytkowania gruntów, głównie wylesianie do celów rolniczych.

Przyjęcie, że wyniki badań naukowych i wnioski z nich wynikające są prawdziwe, ma kluczowe znaczenie dla skuteczności polityki klimatycznej. Jeśli bowiem zmiany klimatu nie byłyby spowodowane przez człowieka, a miałyby charakter naturalny, to prowadzenie działań na rzecz przeciwdziałania im (np. ograniczania redukcji gazów cieplarnianych czy ograniczania wylesiania) nie miałoby sensu. Podobnie, dopóki nie uzna się, że zmiany te zachodzą, a ich skutki mogą mieć poważne, negatywne konsekwencje, dopóty nie będą wspierane działania mające na celu adaptowanie się do skutków tych zmian. Tak więc uznanie przez papieża prawdziwości wyników badań naukowych tworzy moralne uzasadnienie formułowanego przez niego wezwania do podjęcia działań na rzecz ochrony klimatu.

\subsection{Solidarność jako podstawa działań}

Sposób ujęcia kwestii odpowiedzialności za ochronę klimatu w Ramowej konwencji Narodów Zjednoczonych w sprawie zmian klimatu jest charakterystyczny dla ery optymizmu początku ostatniej dekady XX wieku. Po upadku systemu komunistycznego wydawało się bowiem, że zniszczone zostały podstawy podziału pomiędzy państwami, świat wybrał model liberalnej demokracji i w nadchodzących latach będzie się harmonijnie rozwijał. Temu kierunkowi myślenia sprzyjała popularność upowszechnionego w raporcie Brundtland pojęcia zrównoważonego rozwoju, oznaczającego zarówno równoważne traktowanie kwestii ochrony środowiska i zagadnień rozwoju społecznego i gospodarczego, jak i większej solidarności z obecnym i przyszłymi pokoleniami (Brundtland 1987). 
Takie rozumienie solidarności znalazło odzwierciedlenie zarówno w preambule do Konwencji Klimatycznej, jak i w jej art. 4. W preambule stwierdza się, że „największy udział w dawnych i obecnych globalnych emisjach gazów cieplarnianych przypada na państwa wysoko rozwinięte, że emisja tych gazów w przeliczeniu na jednego mieszkańca w państwach rozwijających się jest wciąż względnie niewielka i że udział tych państw w globalnych emisjach gazów będzie wzrastał w związku z potrzebą społecznego i gospodarczego rozwoju tych państw" (B). Dlatego konwencja wskazuje na „wspólną, lecz zróżnicowaną" odpowiedzialność za działania mające na celu powstrzymanie zmian klimatu. Wspólna odpowiedzialność wynika stąd, że skuteczne przeciwdziałanie zmianom klimatu i pozostawienie go w stanie niezagrażającym przyszłym pokoleniom wymaga współpracy wszystkich państw świata. Niezależnie bowiem od tego, w którym kraju nastąpi emisja gazów cieplarnianych, ucierpią na tym wszystkie inne państwa i ich obywatele. Ucierpią również przyszłe pokolenia. Zróżnicowanie odpowiedzialności spowodowane jest historycznym wpływem państw rozwiniętych na klimat: państwa wysoko rozwinięte odprowadzają do atmosfery nadmierną ilość gazów cieplarnianych już od przeszło dwustu lat. Dlatego powinny ponosić one większe obciążenia niż te, w których proces uprzemysłowienia dopiero się rozpoczyna lub trwa od niewielu lat. Co więcej, obecny wysoki poziom rozwoju krajów najbogatszych odbywał się przez całe stulecia kosztem krajów, które dziś należą do najbiedniejszych państw świata. Dlatego też - w imię solidarności i sprawiedliwości historycznej bogata północ powinna przyjąć większe zobowiązania, aby pozwolić krajom południa nadrobić dystans społeczny i gospodarczy, jaki dzieli je od krajów rozwiniętych.

W konsekwencji w Ramowej konwencji na kraje rozwinięte (tzw. państwa Aneksu I do Konwencji) nałożono większe zobowiązania redukcyjne oraz dotyczące wspierania przez nie działań podejmowanych i realizowanych w krajach rozwijających się (w tzw. państwach spoza Aneksu I). Zgodnie z Ramową konwencją Narodów Zjednoczonych w sprawie zmian klimatu z 9 maja 1992 r. to państwa bogate miały do końca XX wieku ustabilizować swoją emisję na poziomie emisji w roku bazowym i to na tej grupie krajów spoczął obowiązek wspierania krajów uboższych w ich wysiłkach na rzecz ochrony klimatu i adaptacji do prognozowanych zmian (B: art. 4). Podejście takie zostało utrzymane w przyjętym w 1997 roku Protokole z Kioto do Ramowej konwencji Narodów Zjednoczonych w sprawie zmian klimatu, który obowiązek redukcji emisji nałożył jedynie na kraje rozwinięte (A).

Niestety, podejście to szybko zaczęło być kontestowane. Dla rządu USA stało się to wygodnym usprawiedliwieniem odmowy ratyfikacji Protokołu z Kioto. W Polsce wielu polityków wskazywało na brak zobowiązań dla krajów rozwijających się jako na przeszkodę do podjęcia bardziej stanowczych działań w naszym kraju. Negocjatorzy chińscy zaś przez wiele lat używali argumentu „zróżnicowanej” odpowiedzialności jako uzasadnienia ogromnego wzrostu emisji gazu cieplarnianych w swoim kraju.

W opinii Ojca Świętego zasada „wspólnej, lecz zróżnicowanej" odpowiedzialności jest słuszna. Powołując się na stanowisko Konferencji Episkopatu USA z 15 czerwca 2001 roku papież jednoznacznie wspiera konieczność zróżnicowania odpowiedzialności poszczególnych państw $w$ działaniach na rzecz ochrony klimatu (Franciszek 2015: 52). Papież pisze o „długu ekologicznym”, które państwa bogatej północy zaciągnęły u krajów ubogich, degradując ich środowisko przyrodnicze i w nadmierny sposób eksploatując ich zasoby naturalne. Jednocześnie zauważa, że proces wyzysku się nie skończył, że nadal koncerny, mające swoje siedziby i właścicieli w krajach bogatych, prowadzą rabunkową gospodarkę w państwach rozwijających się: „[...] zazwyczaj, kiedy zaprzestają działalności i się wycofują, pozostawiają wielkie szkody ludzkie i ekologiczne, takie jak bezrobocie, martwe wioski, 
wyczerpywanie niektórych zasobów naturalnych, wylesienie, zubożenie miejscowego rolnictwa i hodowli zwierząt, kratery, zdewastowane wzgórza, zanieczyszczone rzeki i dzieła społeczne, których nie można już wspierać” (Franciszek 2015: 48).

Odpowiedzią na to powinna być większa solidarność. Większa solidarność bogatszych z tymi, którzy mają mniej. Większa aktywność tych, których stać na finansowanie działań i mają w tym zakresie odpowiednią wiedzę, solidarność z tymi, którzy potrzebują pomocy. A chodzi nie tylko o pomoc finansową, ale także technologiczną i organizacyjną. Przy czym papież za G. Brundtland nie ogranicza swego wezwania do solidarności tylko z obecnym pokoleniem, ale mówi o potrzebie solidarności międzygeneracyjnej i odpowiedzialności ludzi dziś żyjących za stan świata, jaki zastaną ich dzieci i wnuki.

\subsection{Wezwanie do działania}

W encyklice Laudato si' papież bardzo negatywnie ocenia brak skuteczności dotychczasowych wysiłków na rzecz ochrony klimatu. Chociaż w opinii Ojca Świętego bardzo ważne są zmiany technologiczne, które pozwalają na zmniejszenie emisji gazów cieplarnianych do atmosfery (rozwój odnawialnych źródeł energii czy wzrost efektywności energetycznej), to ocena Franciszka dotyczy raczej braku zmian postaw ludzkich, które przyczyniają się do niszczenia klimatu i środowiska, braku odpowiedzialności za słabszych, czy powszechnego braku solidarności decydentów z obecnymi i przyszłymi pokoleniami.

Domagając się zmiany zachowań, papież pyta: „[...] dlaczego usiłuje się dziś zachować władzę, która okazała się niezdolna do interweniowania, gdy było to naglące i konieczne?" (Franciszek 2015: 57). I udziela w encyklice odpowiedzi: wynika to z nadrzędności partykularnych interesów ekonomicznych nad dobrem ogółu. Polityka podporządkowana paradygmatowi wzrostu za wszelką cenę i prymatowi interesu ekonomicznego nad solidarnością nie jest zdolna do rozwiązywania problemów współczesnego świata. Polityka międzynarodowa postrzegana jest przez polityków jako arena budowania pozycji i prestiżu w swoich krajach, a nie jako płaszczyzna szukania porozumienia z innymi. Papież konstatuje gorzko: „Wielu z tych, którzy mają więcej środków i władzy gospodarczej i politycznej, zdaje się koncentrować głównie na maskowaniu problemów lub ukrywaniu objawów" i dodaje „[...] niestety istnieje powszechna obojętność wobec tych tragedii, jakie dzieją się w różnych częściach świata. Brak reakcji wobec tych dramatów naszych braci i sióstr jest oznaką utraty owego poczucia odpowiedzialności za naszych bliźnich, na której opiera się każde społeczeństwo obywatelskie" (Franciszek 2015: 26).

$\mathrm{Na}$ tę ostrą ocenę wpłynęło zapewne to, że encyklika powstawała w okresie, w którym przyszłość globalnego porozumienia klimatycznego nie była pewna. Niepowodzenie konferencji klimatycznej w Kopenhadze w 2008 roku i brak widocznego postępu w negocjacjach w kolejnych latach były spowodowane nieprzygotowaniem większości rządów do współpracy z innymi państwami. Doprowadziło do sytuacji, w której po 2012 roku społeczności międzynarodowej nie obowiązywały żadne restrykcje co do emisji gazów cieplarnianych.

Encyklika nie próbuje przedstawiać gotowych propozycji rozwiązań kryzysu klimatycznego. Jak pisze sam papież, Kościół nie ma wystarczającej wiedzy oraz podstaw, by proponować takie rozwiązania (Franciszek 2015: 25). Nie taka jest też jego rola. Kościół powinien promować uczciwą debatę toczoną przez tych, którzy uznają, że problemy środowiskowe rozwiążą się w zasadzie same poprzez zastosowanie nowych technik, i tych, którzy nawołują do zmniejszenia antropopresji. Papież, opowiadając się za tą drugą wizją, wzywa do aktywności: „[...] ale wystarczy uczciwie spojrzeć na rzeczywistość, aby zobaczyć, że ma miejsce wielka degradacja naszego wspólnego domu. Nadzieja zachęca nas do uznania, że zawsze jest wyjście, że zawsze możemy zmienić kurs, że zawsze 
możemy coś uczynić dla rozwiązania problemów" (Franciszek 2015: 25).

Kluczowe pozostają dla Ojca św. kwestie etyczne i moralne. W jego opinii główną przyczyną niszczenia środowiska przyrodniczego, a więc i klimatu, są chciwość i egoizm, które każą politykom i menadżerom wielkich korporacji dbać tylko o własne interesy, pomijając prawa słabszych i nie dbając o to, jak podejmowane dziś decyzje wpłyną na jakość życia przyszłych pokoleń. Papież stwierdza wprost: „[...] degradacja środowiska przyrodniczego i ludzkiego oraz degradacja etyczna są ze sobą ściśle powiązane" (Franciszek 2015: 56). Zachęcając do zmiany tych postaw, papież ostrzega, że bez niej, nawet gdy będziemy dysponować najdoskonalszymi wynalazkami i technologiami pozwalającymi skutecznie chronić klimat, nasze działania nie przyniosą pożądanego efektu.

Pomimo pesymistycznej diagnozy jakości międzynarodowej polityki Franciszek pozostaje optymistą: „[...] człowiek stworzony do miłości, pośród swoich ograniczeń, jest nieustannie zdolny do gestów wielkoduszności, solidarności i troski” (Franciszek 2015: 58).

\section{Podsumowanie}

Laudato si' to ważny dokument. To głos Kościoła, na który czekały tysiące ludzi zaniepokojonych stanem otaczającego ich świata przyrody. Dokument świadomie kierowany nie tylko do katolików, ale do „wszystkich ludzi dobrej woli”, który wzywa do skuteczniejszego działania na rzecz ochrony środowiska. Choć - jak zaznaczono - nie zawiera on gotowych recept postępowania, wyznacza ich ramy. Wskazuje, że naszym etycznym i moralnym obowiązkiem jest troska o "naszą siostrę Ziemię” i zachowanie jej w stanie, który nie zagrozi przyszłym pokoleniom. Zrozumienie tego wyzwania będzie pierwszym krokiem do stworzenia efektywniejszej polityki klimatycznej.

\section{Bibliografia}

Brundtland G.H. i in. 1987. Our Common Future. Oxford: Oxford University Press.

Carson R. 1962. Silent Spring. Boston: Houghton Milffin Harcourt.

Costella J. (red.). 2010. The Climategate Emials. Melbourne: The Lavoisier Group.

Ferrisi S.A. 2012. Is Benedict the 'Green Pope'? Legatus Magazine 3.06.2012.

Franciszek (papież). 2015. Encyklika Laudato Si'. W trosce o wspólny dom, Kraków: Wydawnictwo M.

Grochowska I. 2010. Benedykt XVI o powinności względem środowiska i integralnego rozwoju człowieka i ludów. W L. Karski, I. Grochowska (red.). Zmiany Klimatu a społeczeństwo, 25-42. Warszawa: Wydawnictwo C.H. Beck.

IPCC. 1990. The First Assessment Report - Overview. Cambridge: The Cambridge University Press.

IPCC. 2001. The Third Assessment Report. Cambridge: The Cambridge University Press.

Jan Paweł II. 1979. Encyklika Redemptor hominis (Rzym, 4.03.1979).

Meadows D.H., Meadows D.L., Randers J., Behrens W.W. III. 1973. Granice wzrostu, Warszawa: Państwowe Wydawnictwo Ekonomiczne.

U’Thant S. 1969. „Człowiek i jego środowisko. Raport Sekretarza Generalnego ONZ” (26.05.1969). Biuletyn Polskiego Komitetu d/s UNESCO (1).

Wang J.M. Oppenheimer. 2005. The Latest Myths and Facts on Global Warming. New York: Environmental Defense Fund.

\section{Akty prawne}

(A) Protokół z Kioto do Ramowej konwencji Narodów Zjednoczonych w sprawie zmian klimatu - Kioto 11.12.1997. Dz. U. 2005 nr 203 poz. 1684.

(B) Ramowa konwencja Narodów Zjednoczonych w sprawie zmian klimatu - Nowy Jork 9.05.1992. Dz. U. 1996 nr 53 poz. 238.

\section{Witryny internetowe}

(Web-01) United Nations Conference on Environment \& Development Rio de Janerio, Brazil, 3 to 14 June 1992, Agenda 21, <https://sustainabledevelopment.un.org/content/documents/Agenda21. pdf >, dostęp: 4.05.2016.

(Web-02) Pociask-Karteczka J. 2007. Przyroda w nauczaniu Jana Pawta II, <www.geo.uj.edu.pl/ j. 
pociask/przyroda_w_nauczaniu_jpii.pdf $>$, dostęp: 10.04.2016.

(Web-03) Jan Paweł II. 1990. Orędzie na XXIII Światowy Dzień Pokoju „Pokój z Bogiem Stwórca, pokój z catym stworzeniem", <http://papiez.wiara. pl/doc/378717.Pokoj-z-Bogiem-Stworca-pokoj-zcalym-stworzeniem-1990 >, dostęp: 10.03.2016.

(Web-04) Global Catholic Climate Movement, <https://catholicclimatemovement.global/pl/>, dostęp: 13.11.2015.

(Web-05) Papież Franciszek na forum ONZ o zmianach klimatu, <http://gramwzielone.pl/ trendy/18271/papiez-franciszek-na-forum-onz-o -zmianach-klimatu>, dostęp: 12.05.2016.

(Web-06) Gers A. 2015. Franciszek w USA: Papież spotkat się z Barackiem Obama, apelowat o ochronę klimatu, <www.gazetakrakowska.pl/ artykul/8179944,franciszek-w-usa-papiez-spotkal -sie-z-barackiem-obama-apelowal-o-ochrone-klimatu-zdjecia-video,id,t.html>, dostęp: 10.04.2016.

(Web-07) IPCC. 2013. Podsumowanie dla Decydentów: Przyczynek I Grupy Roboczej do Piatego Raportu Oceny Zmiany Klimatu Międzyrzadowego Zespotu ds. Zmiany Klimatu 2013: Fizyczne Podstawy Naukowe, Cambridge University Press, Cambridge, Wielka Brytania i Nowy Jork, <www. ipcc.ch/pdf/reports-nonUN-translations/polish/ ar5-wg1-spm.pdf >, dostęp: 10.4.2016.

(Web-08) Jan Paweł II. 1991. Homilia wygtoszona w czasie Mszyśw. beatyfikacyjnej Matki Bolesławy Lament (Białystok, 5 czerwca 1991), <http://ekai. $\mathrm{pl} /$ biblioteka/dokumenty/x425/homilia-wygloszona-w-czasie-mszy-sw-beatyfikacyjnej-matki -boleslawy-lament/?print=1>, dostęp: 10.04.2016.

\title{
Climate Protection as Ethical Challenge. The Climate Protection Issue in the Encyclical Laudato Si'
}

\begin{abstract}
Summary
Halting of the anthropogenic climate change is one of the most important challenges faced by the current generation. This issue is one of the topics raised in Pope Francis' encyclical, Laudato Si'. Based on credible scientific studies showing that man is responsible for the observed changes, the Pope indicates the causes behind the destruction of the climate, points to the scale of its possible consequences and calls for a more active climate policy. However, Laudato $\mathrm{Si}^{\prime}$ focuses on the ethical and moral factors, rather than the present technical attempts at mitigating the climate change.

This aim of this paper is to analyse the ways in which the encyclical calls for climate protection and more active climate policy. It also focuses on analysing the three main challenges which the Pope formulated in this respect, namely, the need to trust in science, the challenge to solidarity and a call for a more proactive decision-making process involving more courage and a greater sense of responsibility.
\end{abstract}

\section{Keywords}

Encyclical Laudato Si'; climate change; climate protection; ethics 